
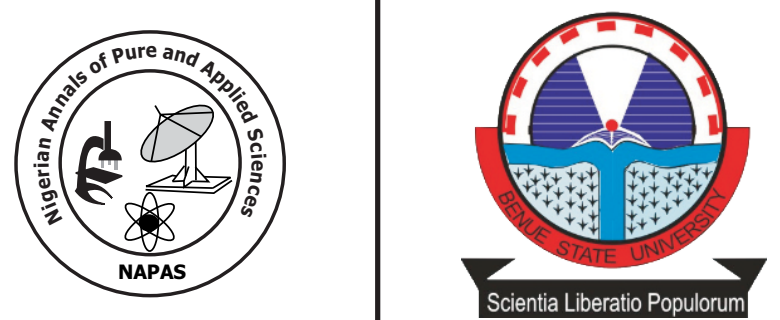

\title{
Production of Bioethanol from Cassava using Zymomonas mobilis: Effect of Temperature and Substrate concentration
}

\section{"Ona, I.J' ${ }^{1}$ Agogo, H.0' ${ }^{2}$, lorungwa, M.S ${ }^{1}$}

1 Department of Chemistry, University of Agriculture Makurdi, Benue State, Nigeria.

2. Department of Petroleum and Gas Engineering Baze University Abuja Nigeria

\section{Abstract}

*Corresponding author:jiona@uam.edu.ng, ikuba.ona@gmail.com

The production of ethanol from cassava flour using Zymomonas mobilis a gram negative bacterium was conducted at $30^{\circ} \mathrm{C}, 33^{\circ} \mathrm{C}, 35^{\circ} \mathrm{C}$ and $37^{\circ} \mathrm{C}$. The fermentation reaction was also carried out at different substrate concentrations; $5 \% \mathrm{~W} / \mathrm{V}, 7 \% \mathrm{~W} / \mathrm{V}$ and $10 \% \mathrm{~W} / \mathrm{V}$. The microorganism Zymomonas mobilis was detected in palm wine, isolated and identified. It was found to be gram negative, oxidase negative, catalase positive, anaerobic and plump rods with an unusual width. Results obtained from the simultaneous saccharification and fermentation reactions carried out with Zymomonas mobilis showed that maximum theoretical ethanol yield of $63 \%$ was obtained for $7 \% \mathrm{~W} / \mathrm{V}$ cassava flour at $35^{\circ} \mathrm{C}$. This was followed by a theoretical yield of 56.23 and 54.12 for $5 \% \mathrm{~W} / \mathrm{V}$ and $10 \% \mathrm{~W} / \mathrm{V}$ cassava flour, respectively. Fermentations at $30^{\circ} \mathrm{C}$ and $33^{\circ} \mathrm{C}$ gave similar results with $7 \% \mathrm{~W} / \mathrm{V}$ cassava producing higher ethanol yield when compared to $5 \% \mathrm{~W} / \mathrm{V}$ and $10 \% \mathrm{~W} / \mathrm{V}$. Fermentation reactions at $37^{\circ} \mathrm{C}$ gave the lowest ethanol yields. The optimum $\mathrm{pH}$ for the simultaneous saccharification and fermentation of cassava was found to be pH of 6 . 


\section{Introduction}

Ethanol production by fermentation has assumed new interest on account of attempts to find substitute for fossil fuel. The available sources of energy generation have become grossly inadequate to meet domestic and industrial needs in the world today. Agricultural fuels or bio-fuels have been seen as alternative sources of energy and bio-fuels still remains a realistic alternative choice because it is a renewable and its use also limits the danger of fossil fuel burnings on the environment. Today, blends of ethanol with gasoline have been satisfactorily used in many countries (Sanchez and Cardona, 2008). Most ethanol fuel produced across the world is derived from corn, sugarcane and other cereals. Ethanol is also produced from cassava with lower yields when compared to yields from sugarcane and other cereals (Sun and Cheng, 2002). The processing of cassava is considered more complex as it would require cooking the root to turn the starch into fermentable sugar. More countries have indicated interest in producing ethanol from cassava. Thailand and China are already known as one of such countries with successful ethanol production programs from cassava. Today, Nigeria ranks as the highest producer of cassava in the world and with vast land mass we can harness this advantage by venturing into ethanol production from cassava starch. Besides its use as fuel, wine, beers, ethanol is an important industrial solvent used in the manufacture of paints, vanishes, perfumes, pharmaceuticals and in food manufacturing industries as flavor (FAO, 2013).

The most common way of bioethanol production is by fermentation using the yeast Saccharomyces cerevisiae with high ethanol yields from starch based substrates. However in recent times, thermophilic bacteria like Zymomonas mobilis have gained attention for their high ethanol yields due to their fast growth rates and ability to ferment a broad variety of both hexoses and pentoses (Georgieva and Ahring, 2007; Koskinen, et al., 2008; Orlygsson and Baldursson, 2007). There are basic differences between yeasts and bacteria. While Saccharomyces cerevisiae ferments sucrose, glucose and fructose to produce ethanol and $\mathrm{CO}_{2}$, Zymomonas mobilis ferments the same sugars to produce ethanol, $\mathrm{CO}_{2}$ and lactic acid. The formation of these products is because bacteria do not follow the glycolytic pathway, like yeasts (Ernandes and Garcia-Cruz, 2011). Zymomonas mobilis has several advantages like lower risk of contamination, increased conversion rates and product recovery. In studies conducted with $Z$. mobilis, some advantages were observed when the aim is industrial ethanol production, highlighting high specific yields; tolerance to high ethanol concentrations; ability to grow in complete anaerobiosis, unlike yeast which requires some oxygen (Behera et al., 2010; Bochner et al., 2010). Z. mobilis, however, has some limitations with respect to its fermentation capacity. To circumvent these problems, genetic manipulation of Zymomonas mobilis has been attempted to broaden its utilizable range. Mutants of Z. mobilis with improved fermentation characteristics have been obtained. The amenability of Zymomonas mobilis to genetic manipulation is one of its distinctive characteristic. Without this gene cloning Obire, (2005) identified Zymomonas species present in the African palm wine as having a better fermentative ability when compared to yeast. He stated that when Zymomonas mobilis is introduced to sugar substrate, more gas is produced than when $S$ cerevisiae alone is introduced. His study also showed that a combination of Zymomonas mobilis and $S$. cerevisiae did not ferment as much as Zymomonas mobilis alone.

Several papers (Nelliah, 1988; Amutha and Gunasekaran, 1994; Gunasekaran et al., 1995) have reported genetically modified Zymomonas mobilis strains ZM4, ATCC 10988, ATC 12526 and NRRL B4286 to ferment several substrates and cassava starch. This paper focused on the efficiency of the bacterium Zymomonas mobilis isolated from the African palm wine in producing bioethanol from hydrolysate of cassava. The paper adopted the simultaneous saccharification and fermentation (SSF) process that involves an initial saccharification by amylase and amyloglucosidase enzymes and consequently uses Zymomonas mobilis to ferment the hydrolysate in the same reaction vessel. Simultaneous Saccharification and Fermentation (SSF) of several starchy substrates for ethanol production have been reported in literature (Gunasekaran et al., 1995) Preference for SSF over the separate hydrolysis and fermentation or batch fermentation process has also been reported in literature (Saigal, 1993; Balat et al., 2008; Pramanik and Rao, 2005).

The paper also studied the effect of substrate concentration, $\mathrm{pH}$ and temperature on the ethanol yield.

\section{Materials and Methods Preparation of Cassava Floor}

The mature cassava tubers were harvested from a farm in Makurdi Benue State, peeled, washed and air dried for one week after which it was grounded into powdered form ready for use. 


\section{Feedstock Characterization}

The analysis of the cassava flour was carried out to determine the residual carbohydrate content. The feedstock characterization assays were performed using the Laboratory Analytical Procedures developed by the United States National Renewable Energy Laboratory and methods developed by the Association of Official Analytical Chemistry (Sluiter et al., 2006a, 2006b, 2004c; Hames et al., 2008).

\section{Isolation of the Microorganism Zymomonas from Palm Wine}

Palm wine was collected by the method of inflorescence tapping from Gidan Waya in Kaduna State. It was collected immediately and placed in a container with ice to slow down the fermentation process. It was then taken to the lab within 2 hours of tapping and then introduced into the prepared media and stored in an anaerobic jar for $24 \mathrm{hrs}$ after which it was observed for the growth of the microorganism.

\section{Preparation of the Detection and Isolation Media}

The isolation medium was prepared by combining the following reagents. Glucose $-10 \mathrm{~g}$, Yeast extract $-3 \mathrm{~g}$, Ethanol $-30 \mathrm{ml}$, Malt extract $5 \mathrm{~g}$. These reagents were then mixed with 1 litre of water and $5 \mathrm{ml}$ of actidione was added and autoclaved for 15 minutes. The isolation medium was composed of Glucose $-15 \mathrm{~g}$, Malt extract $-5 \mathrm{~g}$ Yeast extract $-5 \mathrm{~g}$, Ethanol $-30 \mathrm{ml}$. The compounded components were then put in a conical flask, 1 litre of distilled water was added to it and $5 \mathrm{ml}$ of actidione - an antibiotic was added to it and then it was autoclaved for 15 minutes after being covered with cotton wool and wrapping sheet. After autoclaving, the medium was spread into Petri dishes and stored in the refrigerator.

\section{Detection of Zymomonas mobilis}

Freshly collected palm wine was introduced into $50 \mathrm{ml}$ bottles with durham tubes inserted into those bottles to monitor displacement of gas. The bottles were then transferred into an anaerobic jar and incubated at $30^{\circ} \mathrm{C}$ for 24 hours.

\section{Isolation of Zymomonas mobilis}

Samples were collected form the anaerobic jar by the use of a wire loop having observed displacement of gas in the durham tubes. The sample was then introduced into the spread plates and incubated in an anaerobic jar for 2 days at $30^{\circ} \mathrm{C}$. Colonies suspected to be those of Zymomonas mobilis were then isolated and purified by streaking on freshly prepared media and incubated for another two days in the anaerobic jar. Isolates from the plate were then subjected to the following biochemical test for the characterization of the isolates; Gram stain, oxidase, catalase and carbohydrate fermentation abilities.

\section{Gram Stain}

A smear was prepared with a microscopic slide. The slide was marked and distilled water from a glass was used to smear the glass as it is being sterilized at the same time with a bunsen burner. A sterilized wire loop was then used to transfer to the slide a small portion of the growth to be examined and then it was emulsified in the slope of water until a thin homogenous film is produced, it was then allowed to dry, fix and stain. A solution of crystal violet was applied for 30 seconds. Crystal violet was then replaced with a lugol's iodine solution and allowed to act for $30-$ 60 seconds. Absolute ethanol was then used to rinse until no more colour appeared to flow from the preparation. It was then washed with water. Sufranin was then added for 3 minutes, rinsed with water and dried with gentle heat. It was then monitored using a microscope (Swings and De ley, 1977).

\section{Catalase Activity}

A drop of $10 \% \mathrm{~V} / \mathrm{V}$ hydrogen peroxide was added to the growing organism in a bottle inserted with a durham tube. The bottle is then examined immediately for bubbles of gas to be displaced in the durham tube to indicate catalase activity (Swings and De ley, 1977).

\section{Oxidase Activity}

2-3 drops of oxidase reagents was placed on a piece of filter paper and then colonies of the suspected microorganism were smeared across the same area. A positive oxidase reaction turned the reagent a dark purple colour within 10 seconds (Swings and De ley, 1977).

\section{Preparation of Zymomonas mobilis}

The detection medium was prepared and broth poured into test tubes. Isolates of Zymomonas mobilis was then incubated anaerobically in an incubator at $30^{\circ} \mathrm{C}$. It was then ready for use for fermentation.

\section{Saccharification and Co-Fermentation of Cassava Starch}

The procedure used for this work is the National Renewable Energy Labouratory protocol No 008. The fermentation apparatus; conical flask (250 $\mathrm{ml}$ ), measuring cylinder, gas pipes were all 
washed and sterilized by drying in an oven or rinsed with ethanol. The cassava flour $(5 \mathrm{~g}, 7 \mathrm{~g}$, and $10 \mathrm{~g}$ ) was then weighed and transferred to the conical flask $(250 \mathrm{ml}) .10 \% \mathrm{~V} / \mathrm{V}$ of diluted (1:10) enzymes $(5 \mathrm{ml}$ amylase and $5 \mathrm{ml}$ amylo glucosidase) was then added to the contents and $80 \mathrm{ml}$ of $0.05 \mathrm{M}$ sodium acetate buffer added to the conical flask. The conical flask with its content was then saccharified by heating the conical flask with its contents to $30^{\circ} \mathrm{C} .10 \mathrm{~mL}$ of the Zymomonas mobilis broth is added to the content and fermentation reaction carried out. The process was repeated for $33^{\circ} \mathrm{C}, 35^{\circ} \mathrm{C}$ and $37^{\circ} \mathrm{C}$. The conical flask had contents $5 \% \mathrm{~W} / \mathrm{V}$, $7 \% \mathrm{~W} / \mathrm{V}$ and $10 \% \mathrm{~W} / \mathrm{V}$. Samples are collected at 24 hours, 48 hours and 72 hours. The total reducing sugars were quantified according to 3,5 dinitrosalicylic acid method -DNS Assay (Miller 1959). Ethanol was determined by Gas Chromatography (GC) Shimadzu, using a DBWAX $(30.0 \times 0.25 \mathrm{~cm})$ with a column flux of $40 \mathrm{ml} \mathrm{min} \mathrm{1and} \mathrm{isopropanol} \mathrm{as} \mathrm{an} \mathrm{internal}$ standard. Experiments were carried out in triplicates with a mean results reported. Glucose and ethanol yield was calculated as follows:

\section{$\%$ Yield Glucose $=\quad\left(\right.$ Glucose $\left._{f}\right) \quad X \quad 100$ 1.111F (Mass of Cassava)}

Where Glucose $_{f}$ is the mass of residual glucose in the flask and $\mathrm{F}$ is the carbohydrate fraction of the cassava peels. 1.111 represents the addition of one molecule of water in the conversion of starch to glucose.

$\%$ Yield of Ethanol

$=\left(\right.$ EtOH $\left._{f}\right)-\left(\right.$ EtOH $\left._{0}\right) \quad \mathrm{X} 100$

$0.568 \mathrm{~F}$ (Mass of Cassava)

0.568 represents the total ethanol to be possibly gotten from the biomass by yeast, $\mathrm{EtOH}_{\mathrm{f}}$ - total ethanol at the end of reaction in gram, $\mathrm{EtOH}_{0}$ is the total ethanol at time zero and $\mathrm{F}$ is the carbohydrate fraction of the cassava peels.

\section{Results and discussion \\ Detection, Isolation and Identification of Zymomonas mobilis}

The microorganism Zymomonas mobilis was detected in palm wine, isolated and identified. Colonies suspected to be those of Zymomonas were isolated from the spread plates and purified by streaking on freshly prepared media and incubated for 2 days at $30^{\circ} \mathrm{C}$ in an anaerobic jar. Isolates from these plates were subjected to the following tests for the characterization; Gram stain, catalase and oxidase abilities. Results showed that the microorganism was gram negative, catalase positive, anaerobic, plump rods with an unusual width. It was also hetero fermentative producing gas from glucose, fructose and sucrose. It was oxidase negative. These observations were similar to those reported by Swings and De ley, (1977) on Z. Mobilis isolated from different sources.

\section{Effect of pH}

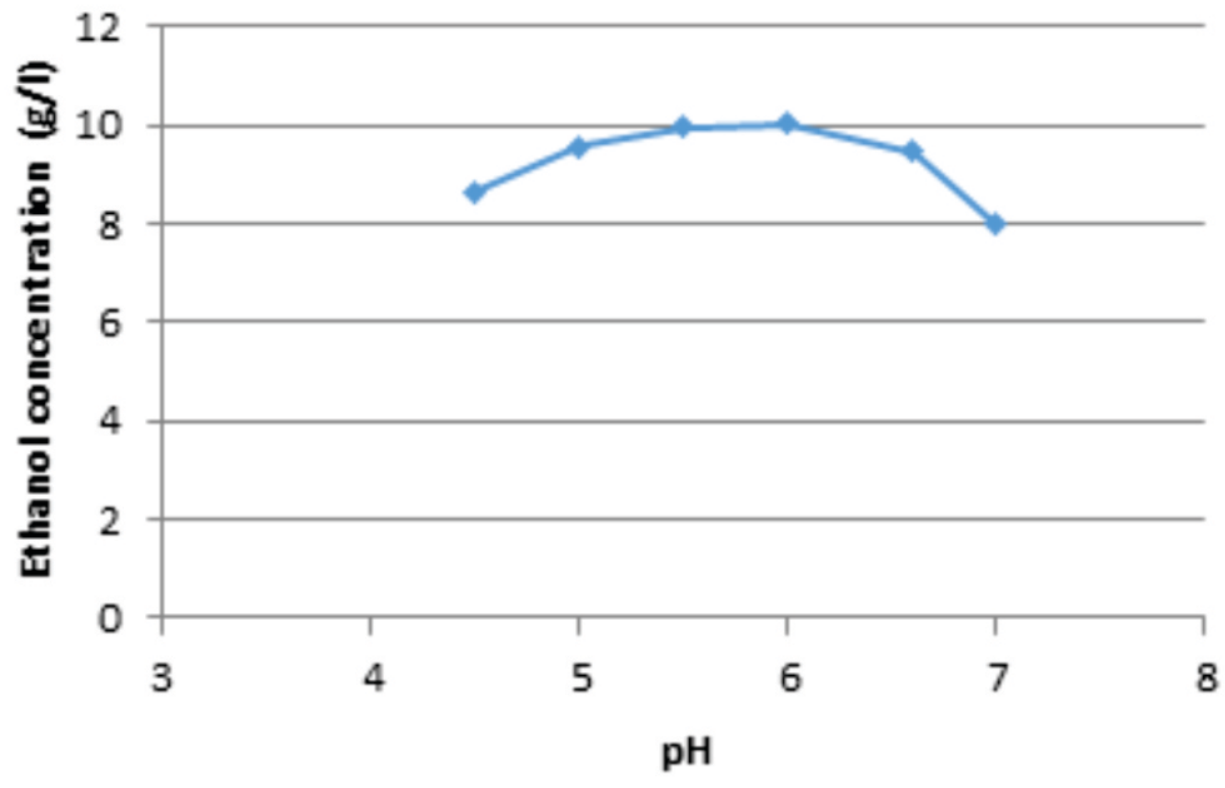

Fig 1: Effect of $\mathrm{pH}$ on ethanol concentration in the fermentation of $5 \% \mathrm{~W} / \mathrm{V}$ cassava flour $30^{\circ} \mathrm{C}$.

Fig 1 shows that the fermentation of cassava peels with Zymomonas mobilis is possible for a wide range of $\mathrm{pH}$, although results showed that maximum ethanol concentration was obtained at $\mathrm{pH}$ of 6. Results obtained at pH 4-6.5 also show high ethanol concentration. 


\section{Effect of Temperature and Substrate Concentration}

Fig 2 and Fig 3 show SSF reactions carried out at $30^{\circ} \mathrm{C}, 33^{\circ} \mathrm{C}, 35{ }^{\circ} \mathrm{C}$ and $37^{\circ} \mathrm{C}$. Maximum ethanol concentration of $18.55 \mathrm{~g} / 1$ was obtained for $7 \% \mathrm{~W} / \mathrm{V}$ cassava floor at $\mathrm{pH} 6$. Results show lower and similar \% theoretical ethanol yields were obtained for fermentations at $30^{\circ} \mathrm{C}$ and $33{ }^{\circ} \mathrm{C}$ $(16.55 \mathrm{~g} / 1$ and $16.85 \mathrm{~g} / \mathrm{l})$ however lowest ethanol yields of $12.9 \mathrm{~g} / 1$ were obtained for reactions carried out at $37^{\circ} \mathrm{C}$. Figure 3 compares $\%$ Theoretical Ethanol yieldss from substrate concentrations of $5 \% \mathrm{~W} / \mathrm{V}, 7 \% \mathrm{~W} / \mathrm{V}$ and $10 \%$ W/V cassava flour at $30^{\circ} \mathrm{C}, 33^{\circ} \mathrm{C}, 35^{\circ} \mathrm{C}$ and $37^{\circ} \mathrm{C}$. Similar trends are observed with $7 \% \mathrm{~W} / \mathrm{V}$ cassava floor having the highest \% theoretical Ethanol yield of 63.12 at $35^{\circ} \mathrm{C}$. Fermentations at $30^{\circ} \mathrm{C}$ and $33^{\circ} \mathrm{C}$ had lower yields of $56.44 \%$ and $57.45 \%$, respectively. The lowest ethanol yield of $44 \%$ was observed for fermentations at $37^{\circ} \mathrm{C}$.

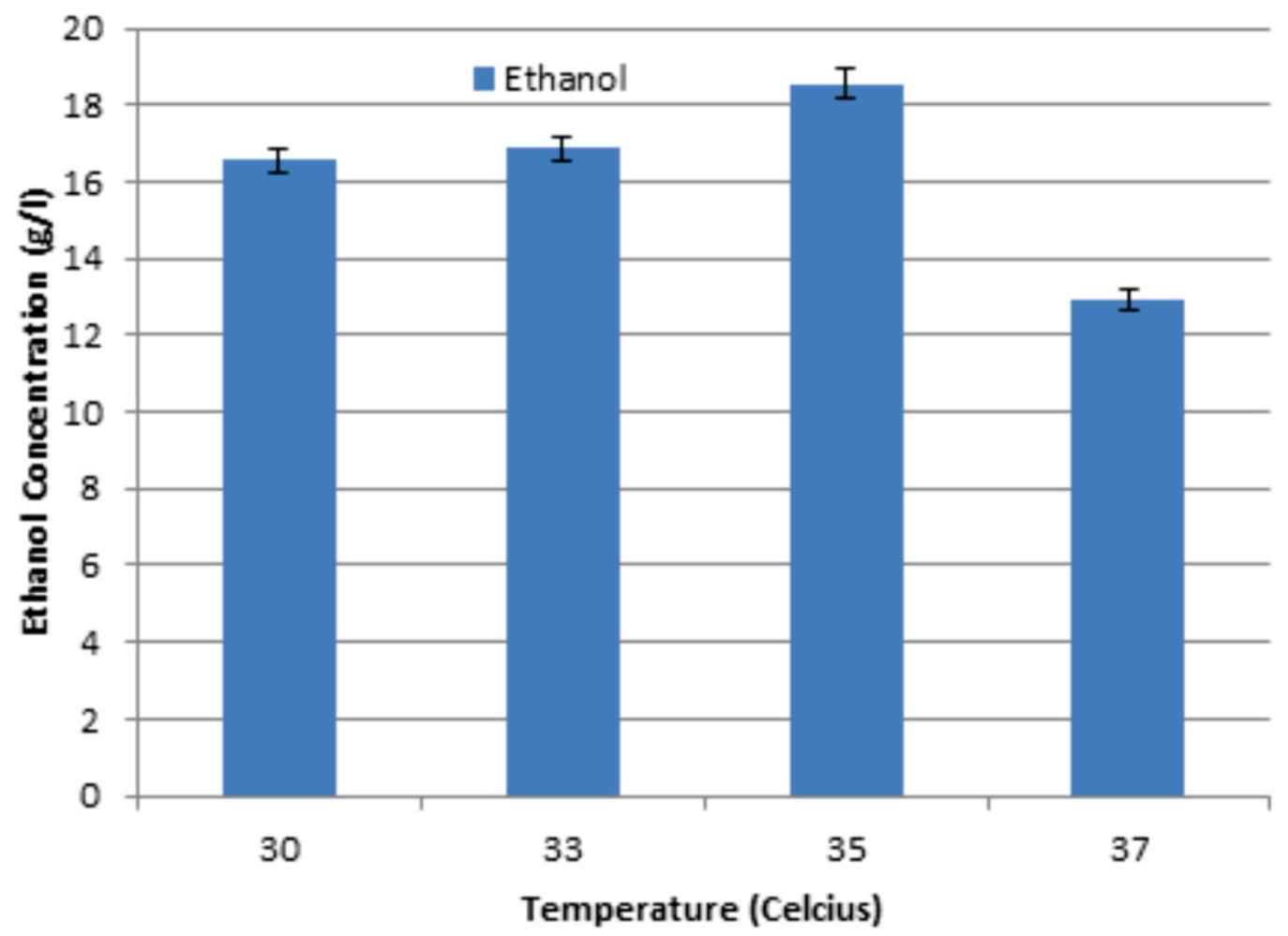

Fig 2: Effect of $\mathrm{pH}$ on ethanol concentration in the fermentation of $7 \% \mathrm{~W} / \mathrm{V}$ cassava flour $30^{\circ} \mathrm{C}, 33$ ${ }^{\circ} \mathrm{C}, 35^{\circ} \mathrm{C}$ and $37^{\circ} \mathrm{C}$ after an initial hydrolysis by $10 \% \mathrm{~V} / \mathrm{V}$ ( amylase + glucoamylase) for 48 hours

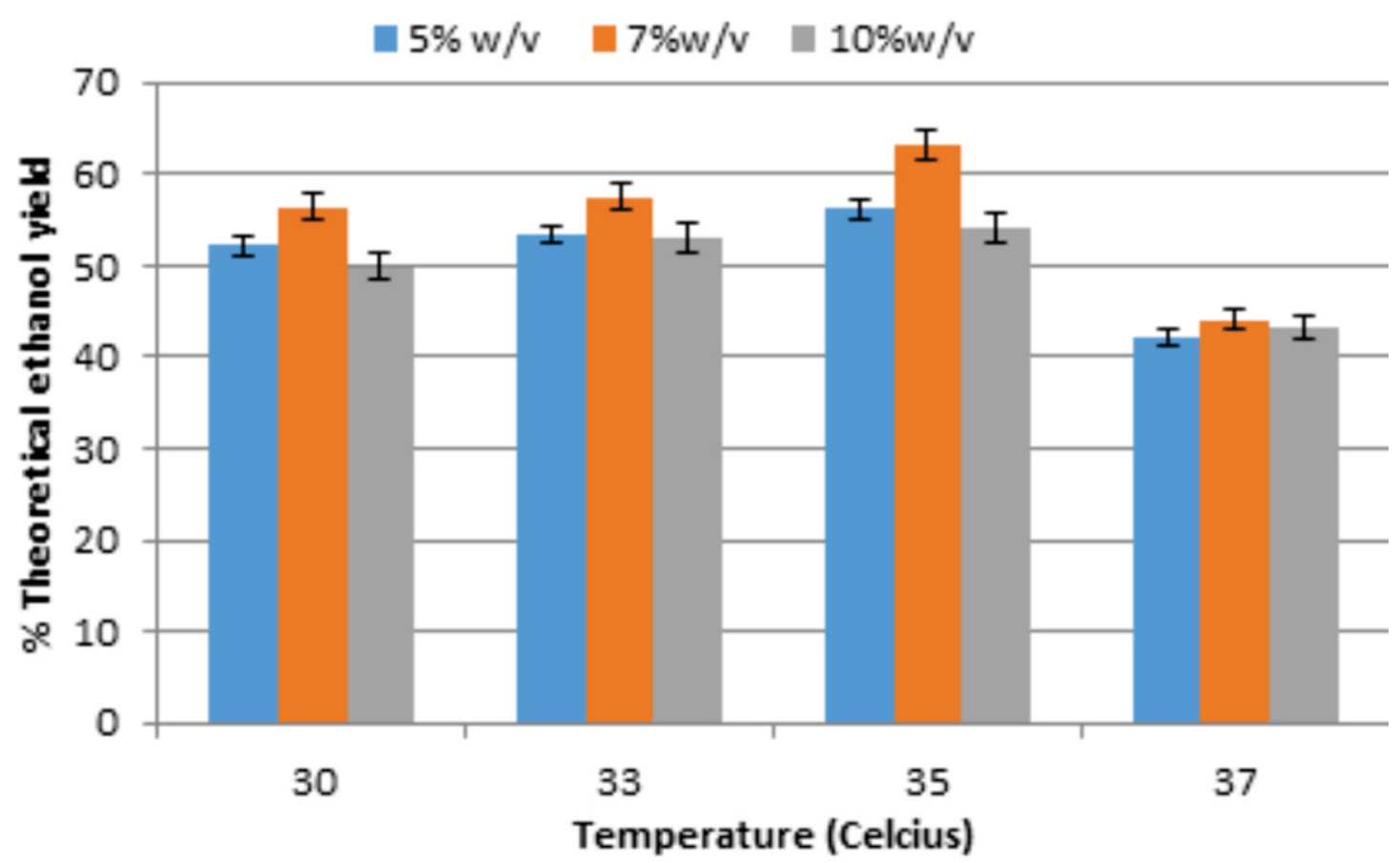

Fig 3: Comparison of the effect of $\mathrm{pH}$ on ethanol concentration in the fermentation of various concentrations of cassava flour at different temperatures after an initial hydrolysis by $10 \% \mathrm{~V} / \mathrm{V}$ (amylase+glucoamylase) 
Reactions at $5 \% \mathrm{~W} / \mathrm{V}$ and $10 \% \mathrm{~W} / \mathrm{V}$ showed the highest theoretical yields of ethanol at $56.23 \%$ and $54.21 \%$ obtained at $35^{\circ} \mathrm{C}$. Further experiments for $5 \% \mathrm{w} / \mathrm{v}$ at $30^{\circ} \mathrm{C}, 33{ }^{\circ} \mathrm{C}$ and $37^{\circ} \mathrm{C}$ show yields of 52.23, 53.42 and $42.11 \%$, respectively. $10 \% \mathrm{w} / \mathrm{v}$ cassava showed the lowest $\%$ theoretical yields compared to $5 \% \mathrm{w} / \mathrm{v}$ and $7 \% \mathrm{w} / \mathrm{v}$ at all temperatures. This might be as a result of high concentration of sugars that are present when substrate concentration is high. These results show that \% theoretical yield of
$49.87,53.11,54.21$, and 43.3 for $30^{\circ} \mathrm{C}, 33^{\circ} \mathrm{C}$ and $37^{\circ} \mathrm{C}$ respectively.

Fig 4 and Fig 5 show the progress curves of these $\mathrm{SSF}$ reactions at $30^{\circ} \mathrm{C}$ and $35^{\circ} \mathrm{C}$. These can be further used to compare the $\%$ theoretical yields at 24, 30, 48 and 72 hours. These results show that reactions carried out at $5 \% \mathrm{~W} / \mathrm{V}$ were completed in 30 hours however reactions carried out at $7 \%$ $\mathrm{W} / \mathrm{V}$ and $10 \% \mathrm{~W} / \mathrm{V}$ were completed in 48 hours. These trends were observed for all temperatures.

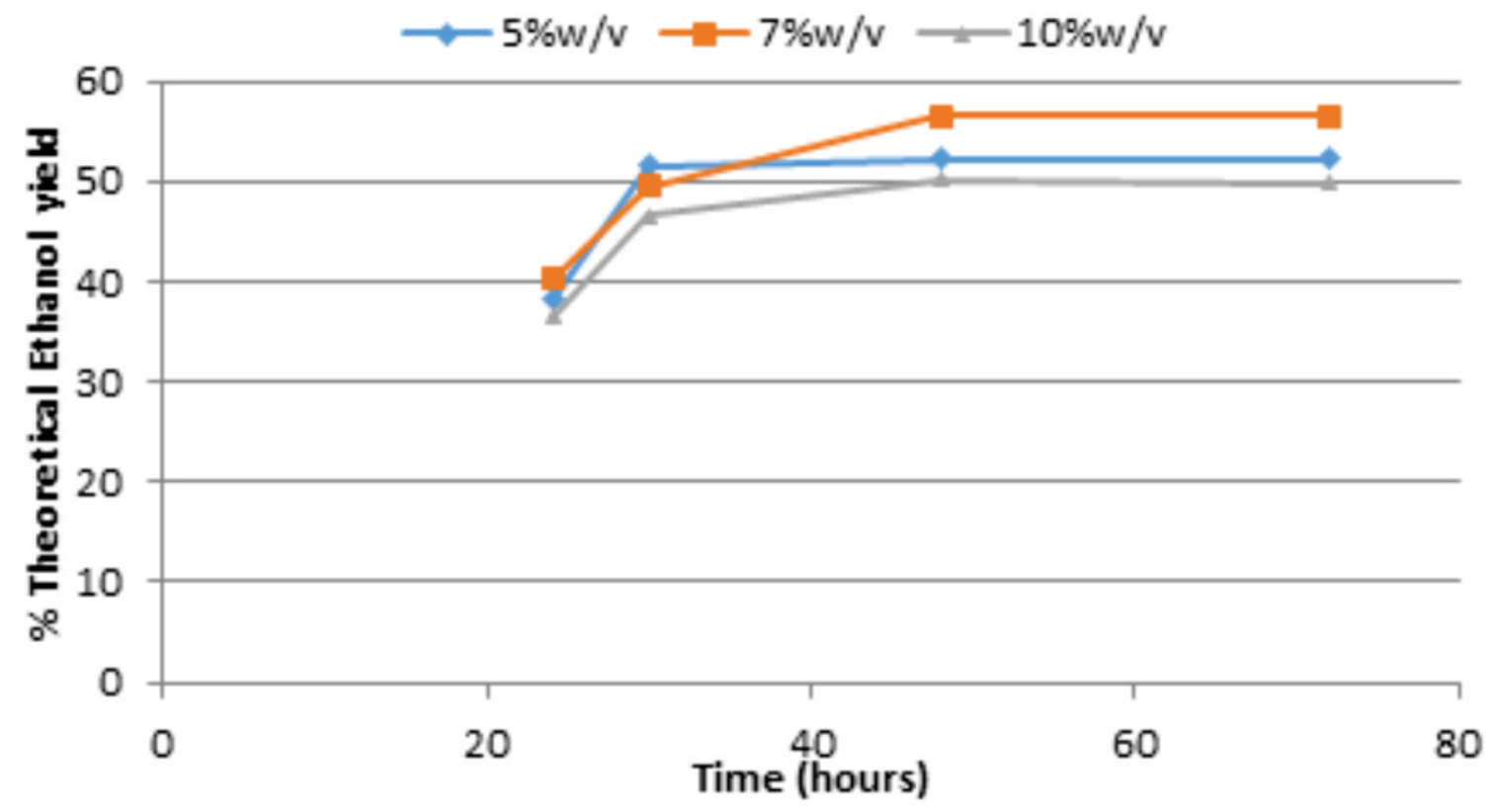

Fig 4: Progress curve of the Simultaneous Saccharification and Fermentation at various concentrations of cassava flour by $10 \% \mathrm{~V} / \mathrm{V}$
(Amylase + Amyloglucosidase) and $10 \% \mathrm{~V} / \mathrm{V}$ Zymomonas mobilis inoculum at $\mathrm{pH} 6$ and a temperature of $30^{\circ} \mathrm{C}$.

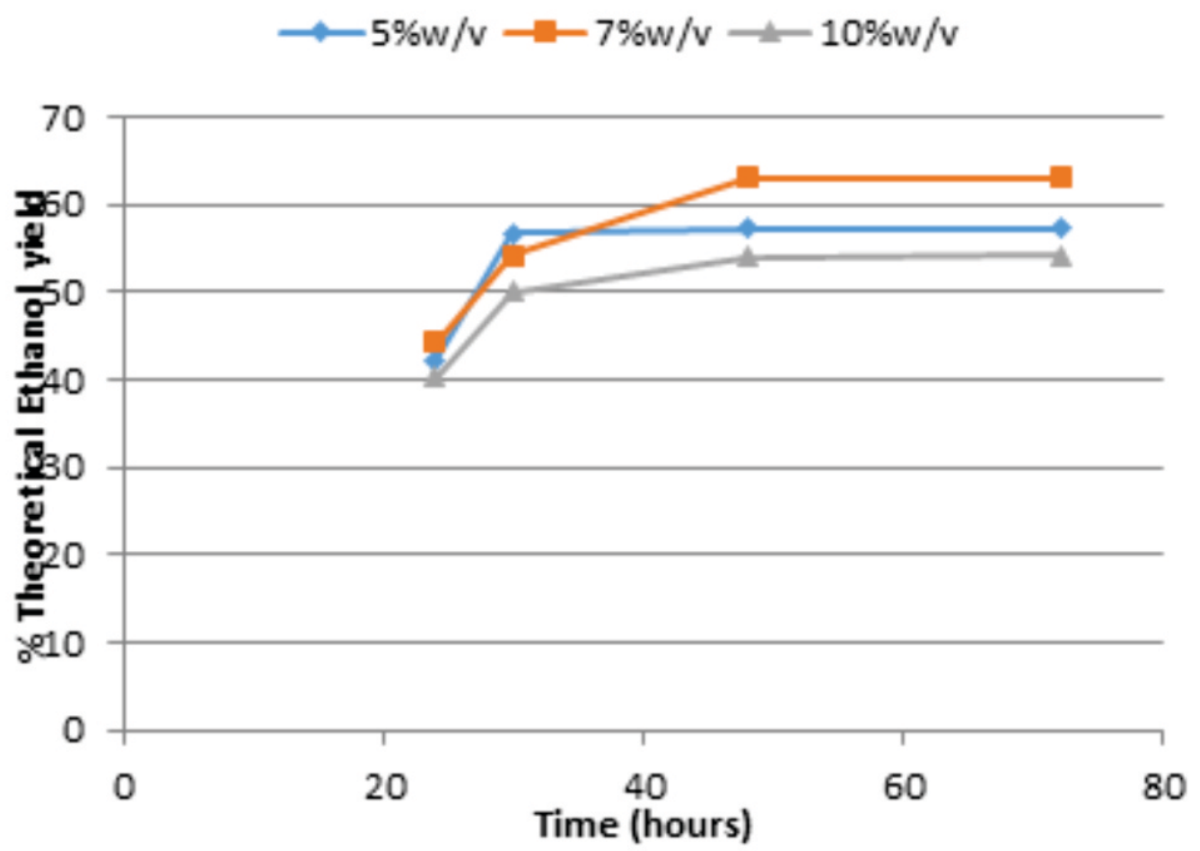

Fig 5: Progress curve of the Simultaneous Saccharification and Fermentation of various concentrations of cassava flour by $10 \% \mathrm{~V} / \mathrm{V}$ (Amylase + Amyloglucosidase) and 10\% V/V Zymomonas mobilis inoculum at pH 6 and a temperature of $35^{\circ} \mathrm{C}$. 
Table 1: Carbohydrate content of cassava flour as estimated by compositional analysis

\begin{tabular}{lc} 
& \% Composition(Mean and Standard Deviation) \\
Starch & $56.20 \pm 0.9$ \\
Cellulose & $17.40 \pm 0.4$ \\
Hemicellulose & $6.38 \pm 0.4$ \\
Total Carbohydrate & 79.98 \\
\hline
\end{tabular}

Table 2: Comparison of the $\%$ reducing sugar yield obtained from saccharification by $10 \% \mathrm{v} / \mathrm{v}$ (Amylase + Amyloglucosidase) against the maximum reducing sugar expected and based on composition cassava after 12,24 and 48 hours.

\begin{tabular}{lllll}
\hline $\begin{array}{c}\text { Cassava Flour } \\
\text { concentration }\end{array}$ & $\begin{array}{c}\text { Maximum Reducing } \\
\text { sugar yield (g/l) }\end{array}$ & $\begin{array}{c}\text { \% Reducing Sugar } \\
\text { yield g/1 } \\
\text { Obtained at 12 hours }\end{array}$ & $\begin{array}{c}\text { \% Reducing Sugar } \\
\text { yield g/1 } \\
\text { Obtained at 24 hours }\end{array}$ & $\begin{array}{c}\text { \% Reducing Sugar yield } \\
\text { g/l }\end{array}$ \\
\hline $5 \% \mathrm{w} / \mathrm{v}$ & 37.4 & 19.23 & 29.92 & 5.52 \\
$7 \% \mathrm{~W} / \mathrm{v}$ & 52.36 & 32.12 & 40.88 & 4.21 \\
$10 \% \mathrm{w} / \mathrm{v}$ & 74.8 & 35.34 & 56.84 & 15.34 \\
\hline
\end{tabular}

Table 1 shows results of the carbohydrate content of the cassava from where the \% theoretical yields were calculated based on the carbohydrate content while Table 2 shows results from the enzyme treatment of cassava to reflect the maximum theoretical yield from the flour.

These results show that Zymomonas mobilis isolated from palm wine is a good alternative microorganism due to its ability to yield a high percentage of ethanol, perhaps due its lower biomas production, its higher ethanol tolerance and its ability to ferment without a controlled addition of oxygen when compared to fermentation by yeast. The simultaneous saccharification and fermentation process offers a viable industrial option that minimizes the cost of separating the sugars after hydrolysis before a fermentation step. While batch fermentation or separate hydrolysis offers an alternative process that maximizes both the hydrolysis and fermentation steps, SSF seeks to study optimum conditions that can favour both the hydrolysis stage and the fermentation stage. Other papers have reported $\mathrm{pH}$ of 6.5 as the optimum for Zymomonas mobilis (Obire, 2005 ; Sivasakthivelan et al., 2014). The Results above (Fig 1) show that $\mathrm{pH}$ of 6 is the optimum. This might be as a result of the balance between the hydrolyzing enzyme and the Zymomonas mobilis. Results also show that $35^{\circ} \mathrm{C}$ is the optimum temperature although studies have shown that $30^{\circ} \mathrm{C}$ is the optimum condition for Zymomonas mobilis (Obire 2005, Behera et al., 2012). This might be attributed to the effect of a higher temperature on the amylolytic enzymes which are known to operate optimally at $50-60^{\circ} \mathrm{C}$. The production of more sugars due to increased saccharification will lead to increased fermentation, however it can also be observed that reactions at $10 \% \mathrm{~W} / \mathrm{V}$ did not show any significant increase in yield. We suggest that it is possible the high concentration of ethanol and glucose associated with increased sugar concentration limits the expected performance of Zymomonas mobilis. A reduction in the percentage theoretical yield at $37^{\circ} \mathrm{C}$ can be attributed to Zymomonas mobilis losing its enzyme activity above $35^{\circ} \mathrm{C}$.

Simultaneous saccharification and fermentation reduces fermentation and completion time. It also affords a beneficial energy savings as the fermenting organism $Z$. mobilis was inoculated along with the amylase and amyloglucosidase enzymes for both saccharification and fermentation were carried out at room temperature $30^{\circ} \mathrm{C}$. Carrying out these experiments in the tropics where temperatures are above $30^{\circ} \mathrm{C}$ shows that these reactions can be carried out at room temperatures for the production of bioethanol.

\section{Conclusion}

In this study, enzyme concentration and volume of inoculum were kept constant. The $\mathrm{pH}$, temperature and substrate concentration were varied with the following results. Maximum ethanol yields of $63 \%$ were obtained for cassava flour concentration of $7 \% \mathrm{w} / \mathrm{v}$ with reactions with SSF completed in 48 hour although SSF with $5 \% \mathrm{w} / \mathrm{v}$ cassava flour was completed in 24 hours with lower ethanol yields. Optimum $\mathrm{pH}$ of 6 was observed for the SSF although similar yields for $\mathrm{pH}$ is obtainable at a wide $\mathrm{pH}$ range of 4-6.5. Optimum temperature for the SSF of cassava flour is $35^{\circ} \mathrm{C}$ however reactions at $30^{\circ} \mathrm{C}$ and $33^{\circ} \mathrm{C}$ gave lower ethanol yields. This paper concludes that Zymomonas mobilis isolated from African palm wine can be used to produce bioethanol at room temperature in the tropics.

\section{References}

Amutha, R. and Gunasekaran, P. J. (1994). Simultaneous saccharification and 
fermentation of cassava starch using Zymomonas mobilis. Microbial Biotechnol. 9:22-34

Behera, S., Mohanty, R., Ray, R. (2010). Ethanol fermentation of mahula (Madhuca latifolia) flowers using free and immobilized bacteria lowers using free and immobilized bacteria Zymomonas mobilis MTCC 92. Biologia 65(3):416-421.

Behera. S., Mohanty, R.C, Ray, R.C (2012b). Ethanol fermentation of sugarcane molasses by Zymomonas mobilis MTCC 92 immobilized in Luffa cylindrica L. sponge discs and Ca-alginate matrices. Braz. J. Microbiol. 43(4):1499-1507.

Bochner. B, Gomez, V., Ziman, M., Yang. S., Brown, S.D (2010). Phenotype microarray profiling of Zymomonas mobilis ZM4. Appl. Biochem. Biotechnol. 161(1-8):116-123.

Ernandes, F.M.P.G., Garcia-Cruz, C.H (2011). Zymomonas mobilis: a promising microorganism for fermentation. Semina: Ciencias Agrarias 30: 361-380

FAO (2013) Analysis of incentives and disincentives for C a s a v a i $\mathrm{Nig}$ e ri a http://www.fao.org/3/a-at582e.pdf. Accessed 16 September 2018

Georgieva, T.I. and Ahring, B.K., (2007). Evaluation of the continuous fermentation of dilute-acid corn stover hydrolysate using the thermophilic anaerobic bacterium Thermoanaerobacter BG1L1. Applied Microbiology and Biotechnology, 77: 61-68.

Gunasekaran, P., Mukundan, G., Kannan, T. R., Velmurugan, S., Ait-Abdelkader, N., AlvarezMacarie, E. and Baratti, J., (1995). The sacB and sacC genes encoding levansucrase and sucrase form a gene cluster in Zymomonas mobilis. Biotechnol. Lett., 17:635-642

Koskinen, P.E.P., Beck, S.R., Orlygsson, J.O. and Puhakka, J. (2008). Ethanol and hydrogen production by two thermophilic, anaerobic bacteria isolated from Icelandic geothermal areas. Biotechnology and Bioengineering, 101: 679-690.

Balat, M. Balat, H and Oz, C. (2008). Progress in Bioethanol Processing. Progress in Energy and Combustion Science, 34:551-573

Miller, G.L. (1959). Use of dinitrosalicylic acid reagent for determination of reducing sugar. Anal.Chem 31:426-8

Nellaiah, H., Karunakaran, T. and Gunasekaran, P., (1988). Ethanol fermentation of cassava starch by Zymomonas mobilis NRRL-B. 428. Biomass. 15:201-207.
Nellaiah, H., Karunakaran, T. and Gunasekaran, P., J. (1988). Ethanol fermentation by an efficient strain NRRL-B 4286 of Zymomonas mobilis Ferment. Technol. 66:219-223.

Orlygsson, J. and S.R.B. Baldursson, 2007. Phylogenetic and physiological studies of four hydrogen-producing thermoanaerobes from the Icelandic and geothermal areas. Icelandic Agricultural Sciences, 20: 93-106.

Orlygsson, J. and Baldursson, S.R.B. (2007). Phylogenetic and physiological studies of four hydrogen-producing thermoanaerobes from the Icelandic and geothermal areas. Icelandic Agricultural Sciences, 20: 93-106.

Pramanik, K. and Rao, D.E. (2005). Kinetic study on ethanol fermentation of grape waste using Saccharomyces cereviseae IE(I) Journal-. CH 85: 53-58.

Saigal, D (1993). Yeast strain development for ethanol production. Indian Journal of Microbiology 33:159-168

Sanchez, O. J. and Cardona, C. A. (2008). Trends in biotechnological production of fuel ethanol from different feedstocks. Bioresource Technology, 99(13), 5270-5295.

Sluiter. A., Hame,s B., Ruiz, R., Scarlata, C., Sluiter, J., Templeton, D., Crocker, D. (2008). Laboratory analytical procedure for the determination of structural carbohydrates and lignin in biomass. National Renewable Energy Laboratory. Technical Report NREL/TP-510-42618

Sluiter. A., Hame,s B., Ruiz, R., Scarlata, C., Sluiter, J., Templeton, D., (2006).Laboratory analytical procedure for the determination of sugars, byproducts, and degradation products in liquid fraction process samples. National Renewable Energy Laboratory. Technical Report NREL/TP-510-42623

Sluiter. A., Hame,s B., Ruiz, R., Scarlata, C., Sluiter, J., Templeton, D., and Crocker, D. (2008). Laboratory analytical procedure for the determination of structural carbohydrates and lignin in biomass. National Renewable Energy Laboratory. Technical Report NREL/TP-510-42618

Sluiter, A., Sluiter, J. (2008). Laboratory analytical procedure for determination of starch in solid biomass samples by HPLC. National Renewable Energy Laboratory. Technical Report NREL/TP-510-42624

Sun, Y. and Cheng, J. Y. (2002) Hydrolysis of lignocellulosic materials for ethanol production: a review. Bioresource Technology, 83(1), 1-11 